\title{
Recent Developments in Cross-Border Investment in Securities
}

Carol C. Bertaut and William L. Griever, of the Board's Division of International Finance, prepared this article. Jillian E. Faucette provided research assistance.

Securities have replaced bank lending in recent years as the primary means through which funds are invested internationally, and in the process, the share of U.S. securities owned by foreigners has grown markedly. For example, between December 1974 and June 2002, the proportion of the value of outstanding U.S. equities and long-term debt securities that was foreign-owned increased from about 5 percent to about 12 percent. ${ }^{1}$ During the same period, the value of these foreign holdings increased from $\$ 67$ billion to almost $\$ 4$ trillion.

U.S. holdings of foreign long-term securities have also increased over this period, although their growth has not matched the rapid growth in foreign holdings of U.S. long-term securities. At $\$ 1.8$ trillion, the value of U.S. holdings of foreign long-term securities at the end of 2002 was less than half the value of foreign holdings of U.S. securities; this difference resulted in a negative net international position in long-term securities of $\$ 2.3$ trillion. This disparity is also reflected in the more comprehensive U.S. international investment position, which is the value of all U.S. holdings of foreign assets minus the value of all foreign holdings of U.S. assets (chart 1). On this more comprehensive basis, the United States has for some years been the world's largest net debtor country. In recent years, the path of the net international investment position has closely mirrored that of the net long-term securities position.

The U.S. system for measuring cross-border investment in long-term securities consists of annual sur-

1. Hereafter we will refer to this set of instruments, whether of foreign or U.S. origin, as long-term securities. Long-term debt has an original maturity of more than one year. All holdings of securities mentioned in this report pertain to portfolio investment holdings and exclude direct investment holdings. Direct investment means the ownership or control, directly or indirectly, by one person or by a group of affiliated persons, of 10 percent or more of the voting stock of an incorporated business enterprise, or an equivalent interest in an unincorporated enterprise.
1. Net U.S. international investment position and net U.S. long-term securities position, 1976-2002

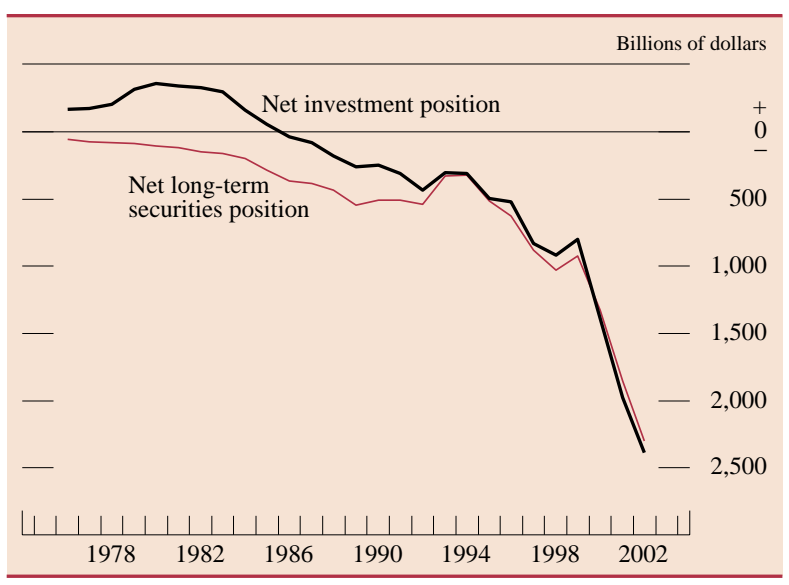

NotE. Direct investment is valued on a current-cost basis. See text note 1 for definition of long-term securities as used here and in subsequent charts.

Source. Bureau of Economic Analysis, Survey of Current Business; and the Treasury International Capital reporting system.

veys measuring holdings of securities and monthly reports measuring transactions in securities. ${ }^{2}$ The data are part of the Treasury International Capital (TIC) reporting system (www.treas.gov/tic). The data on holdings are collected on a security-by-security basis, whereas the transactions data are collected on an aggregated basis. Because the holdings data are security-specific, they permit extensive verification and are thus considered highly reliable. But because the data require thorough editing, they are available only after a lag of about one year. The transactions data, in contrast, are available after only forty-five days; they provide information on the magnitude and geography of recent cross-border flows as well as a broad categorization of the types of instruments giving rise to these flows. Estimates of securities hold-

2. Surveys of foreign holdings of U.S. securities (liabilities) are conducted as of June 30, and surveys of U.S. holdings of foreign securities (assets) are conducted as of December 31. The annual surveys consist of a benchmark survey every five years and only slightly smaller sample surveys in the intervening years. The smaller surveys collect data from the largest reporters in the most recent benchmark survey that collectively accounted for approximately 90 percent of the data reported on that survey. 
ings can be updated with the more-recent data on transactions. $^{3}$

This article reports the latest survey data on holdings as well as the more-recent transactions data. The discussion focuses on U.S. cross-border securities activity, but it also addresses the investment patterns of some other countries and describes initiatives to improve the measurement of cross-border securities investments.

\section{FOREIGN HOLDINGS OF U.S. SECURITIES}

The most recent survey results available for foreign holdings of U.S. long- and short-term securities are as of June 30, 2002. The survey measure of foreign holdings was $\$ 4.3$ trillion, of which $\$ 1.4$ trillion was equity, $\$ 2.5$ trillion was long-term debt, and $\$ 0.4$ trillion was short-term debt. Residents of Japan and the United Kingdom were the largest portfolio investors in U.S. long-term securities by a wide margin (chart 2). The investment patterns of these two countries were quite different, however, with U.K. residents owning slightly more equity than debt and Japanese residents showing a marked preference for U.S. debt. These two countries have also been the top holders of U.S. securities in each of the past four surveys, with Japan having the largest holdings in

3. For a comprehensive discussion of the U.S. system for measuring cross-border securities activity, including a description of the methodology for computing estimated holdings, see William L. Griever, Gary A. Lee, and Francis E. Warnock, "The U.S. System for Measuring Cross-Border Investment in Securities: A Primer with a Discussion of Recent Developments," Federal Reserve Bulletin, vol. 87 (October 2001), pp. 633-50, available at www.federalreserve.gov/pubs/bulletin/2001/1001lead.pdf.

2. Foreign holders of U.S. securities, by selected country of residence, June 30, 2002

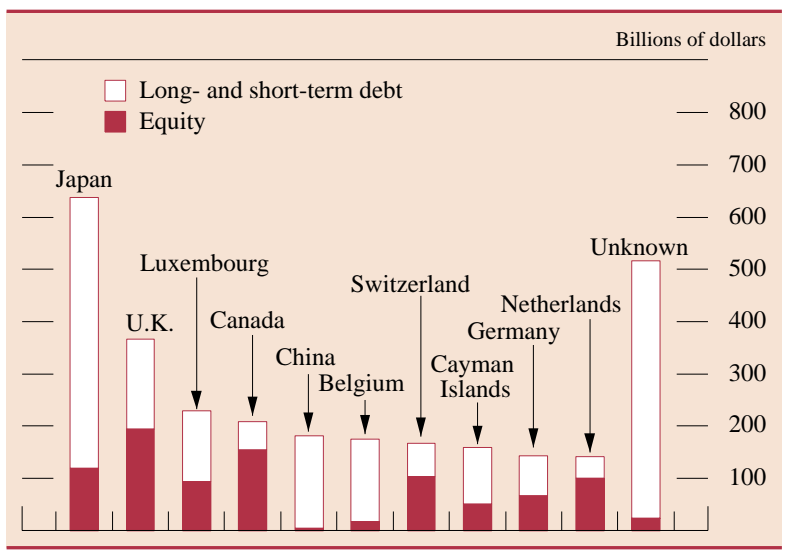

NoTE. Such holdings by all other countries total $\$ 1.4$ trillion.
1989 and 1994 and the United Kingdom having the largest in 2000 (not shown in chart). ${ }^{4}$

Although data on the total level of foreign holdings of U.S. securities as measured by the surveys are considered reliable, the country attribution of these holdings is far from perfect, mainly because of two problems. The first problem arises when the foreign owner of a U.S. security entrusts the safekeeping of the security to an institution that is neither in the United States nor in the foreign owner's country of residence. For example, a resident of Germany may buy a U.S. security and place it in the custody of a Swiss bank. Normally the Swiss bank will then employ a U.S.-resident custodian bank to act as its foreign subcustodian for the security to facilitate settlement and custody operations. When portfolio surveys are conducted, information is collected only from U.S.-resident entities. Thus, the U.S.-resident bank, acting as the subcustodian of the Swiss bank, will report this security on the survey. Because the U.S. bank will typically know only that it is holding the security on behalf of a Swiss bank, it will report the security as Swiss-held. Among the countries with the largest holdings of U.S. securities, five of themBelgium, the Cayman Islands, Luxembourg, Switzerland, and the United Kingdom - are financial centers in which substantial amounts of securities owned by residents of other countries are held in custody. Perhaps the greatest distortion in country attribution is reflected in the level of holdings attributed to Luxembourg, a country with an estimated gross domestic product of $\$ 20$ billion in 2002 that is credited with holdings of \$229 billion.

The second problem affecting country attribution is caused by bearer, or unregistered, securities. Usually, little or no information is available on the owners of these securities because they need not make themselves known. Bearer securities generally cannot be issued in the United States, but U.S. firms can and do issue such securities abroad. The vast majority of the $\$ 492$ billion in debt securities attributed to owners whose country of residence is unknown are bearer securities.

The percentage of U.S. long-term securities that are foreign-owned has increased significantly over time, particularly in recent years (chart 3, top panel). On a share basis, foreign investment is highest in U.S. Treasury securities: Foreign investors owned 41 percent of the total outstanding as of June 30, 2002 (chart 3, second panel). Foreign official institutions, which consist mainly of central banks and other

4. For findings from the survey, see www.treas.gov/tic/fpis.html. 
3. Foreign holdings of U.S. long-term securities as a share of such securities outstanding,

December 1974-June 2002

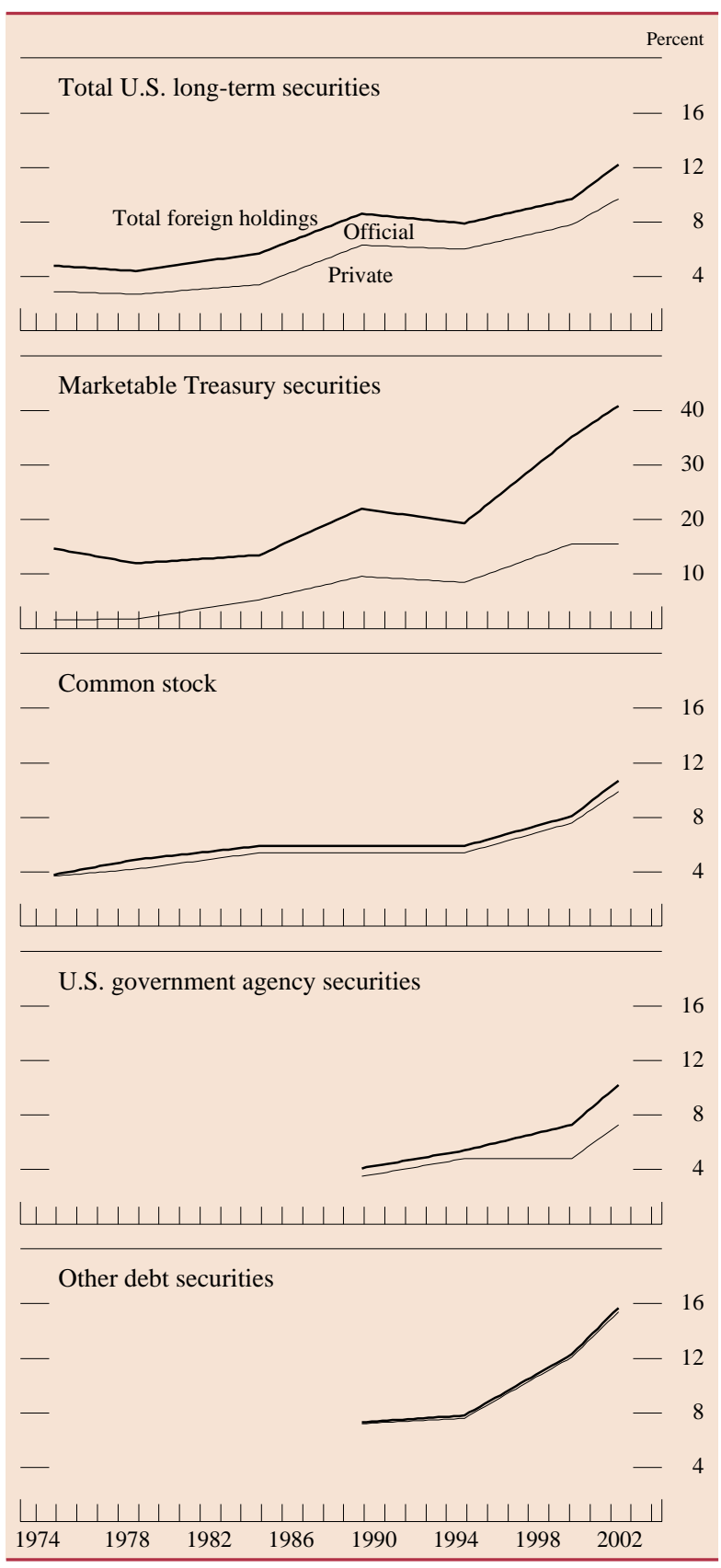

NoTE. Other debt securities are primarily corporate and municipal debt. All panels show total, official, and private foreign holdings.

foreign government bodies responsible for conducting monetary policy or stabilizing exchange rates, are the primary foreign holders of long-term U.S. Treasury securities. We present data for official institutions separately because the motivations of official and private investors may differ. Foreign ownership of other classes of U.S. securities ranges from 11 per- cent to 16 percent of the total outstanding and consists mainly of holdings of foreign private investors (chart 3, bottom three panels).

\section{FOREIGN INVESTMENT PATTERNS}

We gain another useful perspective on foreign holdings of U.S. securities by examining what fraction of a country's total investment in securities is held in U.S. securities and by comparing that fraction with its holdings of foreign securities more generally. For data on each country's total holdings of foreign securities, we use the 1997 and 2001 Coordinated Portfolio Investment Surveys (CPIS), discussed later in this article. As explained in the appendix, we also compare the CPIS data on holdings of U.S. securities with our estimates as derived from the U.S. liabilities surveys.

For estimates of each country's holdings of domestic equities and domestic long-term debt, we use the country's financial balance sheets. The holdings of domestic securities, combined with the CPIS estimates of holdings of foreign securities, give a measure of each country's total portfolio investment in equities and long-term debt. The following charts include only the countries for which all the relevant data could be found.

We compare foreign portfolio holdings with a standard model of portfolio allocation, the international capital asset pricing model, or ICAPM. If all investors followed the ICAPM, the proportions of equities and long-term debt securities in their portfolios would match the market shares of these securities. For example, as of year-end 2001, U.S. equities made up 50 percent of all equities outstanding worldwide (chart 4, left panel). The U.S. share of the global long-term debt market was 45 percent (chart 4 , right panel). ${ }^{5}$ Thus, if U.S. securities were distributed in foreign portfolios at year-end 2001 according to the ICAPM allocation, each country would hold 50 percent of its equity portfolio and 45 percent of its long-term debt portfolio in U.S. securities. To assess how close foreign portfolios come to this distribution

5. Global long-term debt market shares are staff calculations derived from unpublished estimates by the Bank for International Settlements (BIS) of domestic long-tem debt and from published BIS estimates of long-term international debt adjusted to include estimates of Brady bonds from Merrill Lynch, Size and Structure of the World Bond Markets: 2002. See John D. Burger and Francis E. Warnock, "Foreign Participation in Local Currency Bond Markets," International Finance Discussion Papers (Board of Governors of the Federal Reserve System, forthcoming). 
4. Share of each country's domestic securities in the global securities markets, December 31, 2001

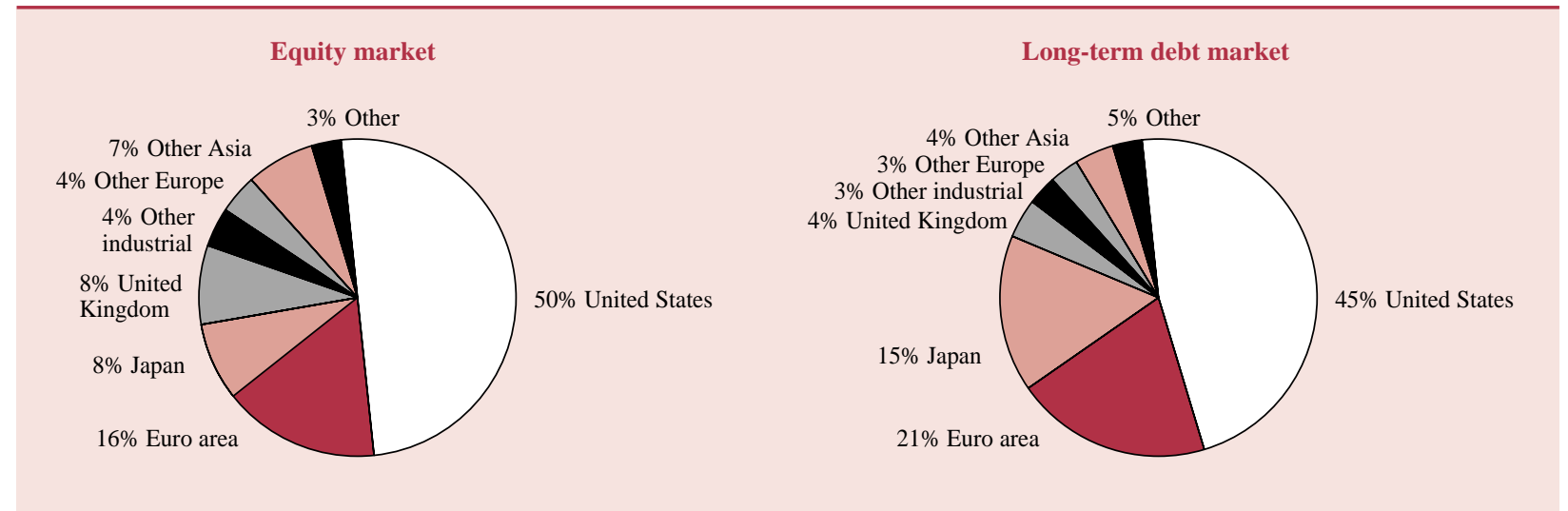

Note. The euro area consists of countries that were members of the euro area as of December 2001: Austria, Belgium, Finland, France, Germany, Greece, Ireland, Italy, Luxembourg, the Netherlands, Portugal, and Spain.

Other Asia: China, Hong Kong, India, Indonesia, Israel, Korea, Malaysia, the Philippines, Singapore, Taiwan, and Thailand.

pattern, we construct a measure for a country's portfolio weight of U.S. securities:

$$
\begin{aligned}
& \begin{array}{l}
\text { Portfolio weight of } \\
\text { U.S. securities } \\
\text { for country X }
\end{array} \\
& \text { size of U.S. market }
\end{aligned}
$$

Thus, if a country holds half of its equity portfolio in U.S. equities, the portfolio weight will be 1 . A value of less than 1 implies that the portfolio is underweight in U.S. securities relative to the ICAPM distribution; a value of greater than 1 implies that the portfolio is overweight in U.S. securities.

We perform a similar calculation to determine whether a country's total holdings of foreign securities are consistent with the size of foreign markets, where the foreign market for each country is defined as the global market excluding that country's domestic securities:

$$
\begin{aligned}
& \begin{array}{l}
\text { Portfolio weight of } \\
\text { foreign securities } \\
\text { for country } X
\end{array} \\
& \text { X }
\end{aligned}=\frac{\frac{X^{\prime} \text { s foreign holdings }}{X^{\prime} \text { s total holdings }}}{\frac{\text { size of foreign market }}{\text { size of global market }}}
$$

In this case, the weight can also be thought of as a measure of "home bias," as it will be 1 if the share of foreign assets in a country's portfolio equals the share of foreign assets in the global market. A value of less than 1 implies an underweight in foreign
Other Europe: The Czech Republic, Denmark, Hungary, Norway, Poland, the Russian Federation, Sweden, Switzerland, and Turkey.

Other industrial: Australia, Canada, and New Zealand.

Source. For the equity market, Standard \& Poor's Global Stock Market Factbook 2003. For the long-term debt market, see text note 5 .

securities and a corresponding overweight in domestic securities - that is, home bias.

We can visually portray these portfolio weights for equities and, for countries for which we have observations in both 1997 and 2001, the direction of movement of the weights (chart 5). The horizontal axis is the weight of all foreign equities, and the vertical axis

5. Portfolio weights of U.S. equities and of all foreign equities for selected countries, December 31, 1997 and 2001

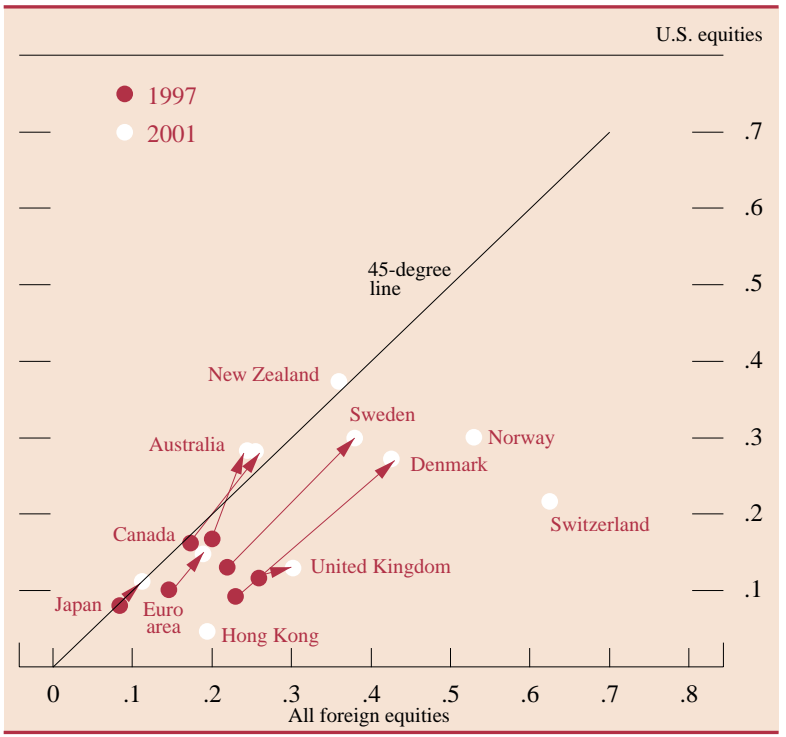

Note. The euro area is a weighted average of countries in the euro area for which we can construct portfolio weights in both 1997 and 2001: Austria, Belgium, Finland, France, Italy, the Netherlands, and Spain. Foreign securities for the euro area are defined as holdings reported in the Coordinated Portfolio Investment Survey for each country excluding securities of other countries in the euro area. For calculation of the weights and discussion of the data in relation to the 45-degree line, see text. 
is the weight of U.S. equities. For example, the dot for Hong Kong indicates a considerable underweight in total foreign equities in 2001 and an even greater underweight in U.S. equities.

For countries with observations in both 1997 and 2001, the arrows show the direction of movement. A vertical movement would indicate that although a country kept the total foreign share of its equity portfolio unchanged between 1997 and 2001, U.S. equities gained at the expense of other foreign equities. A movement along the 45-degree line would indicate a balanced expansion of U.S. and foreign equities relative to the portfolio allocation based on market capitalization. The arrows indicate that all countries for which we have 1997 data increased their international diversification into both U.S. and total foreign equities. The increases were notable for Australia, Canada, Denmark, and Sweden and were smaller for countries with fairly deep domestic capital markets (the euro area, Japan, and the United Kingdom).

We also show the portfolio weights and movements in U.S. and all foreign long-term debt for the same countries, with the addition of four Asian countries that were important holders of U.S. long-term debt in 2001 (chart 6). The portfolio weights of U.S. long-term debt increased for several countries, but the results were less uniform than those for equities. For the United Kingdom and Japan, the weight of U.S. long-term debt decreased a bit between 1997 and

6. Portfolio weights of U.S. long-term debt and of all foreign long-term debt for selected countries, December 31, 1997 and 2001

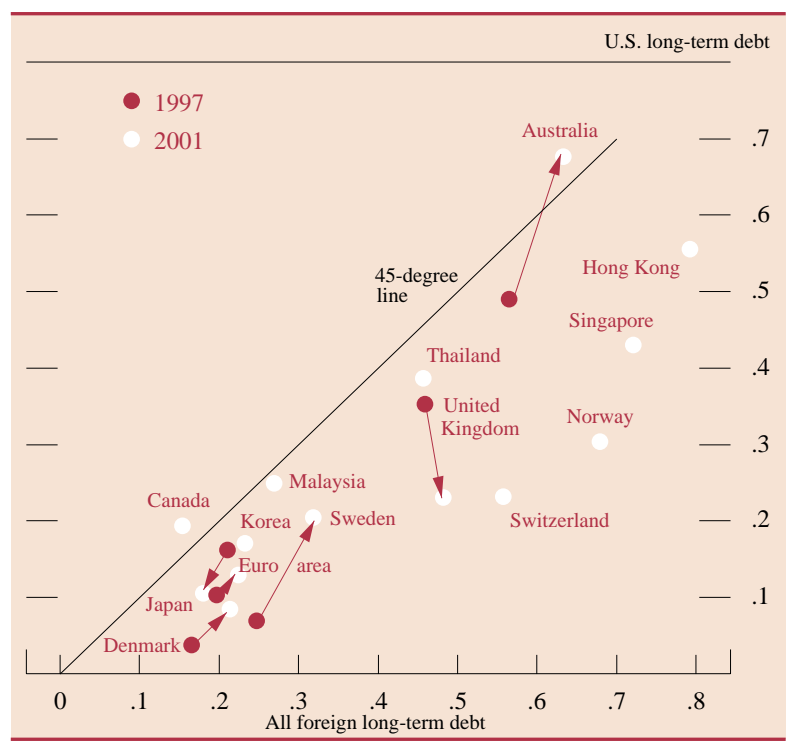

Note. See note to chart 5 .
2001 despite an increase in actual holdings of U.S. long-term debt over this period.

In sum, greater international diversification appears to have been associated with an increased willingness to hold U.S. equities, but it is difficult to draw a conclusion about any change in the appetite for holding U.S. long-term debt. The preponderance of dots below the 45-degree line does indicate, however, that most of these countries are more underweight in U.S. assets than in foreign assets in general. ${ }^{6}$

Recently researchers have pointed out that the ICAPM applies only to investors who purchase and hold freely traded securities in the global market. ${ }^{7}$ To compare actual portfolio shares with the ICAPM distribution, the equity market shares portrayed in chart 4 should be adjusted for differences in "float" in various countries. "Float" refers to the fraction of each country's equity that is freely traded. It excludes equities that are closely held and thus unlikely to be offered for sale. It also excludes equity that is subject to foreign ownership restrictions. Making such an adjustment increases the U.S. share of the global equity market in 2001 to 58 percent. $^{8}$ Adjusted for float, the relative underweight in U.S. equities displayed for the countries shown in chart 5 would be somewhat more pronounced. ${ }^{9}$

\section{U.S. HOLDINGS OF FOREIGN SECURITIES}

The most recent survey results available for U.S. holdings of foreign securities are as of year-end 2001. The survey measure of U.S. holdings of foreign securities was $\$ 2.3$ trillion, of which $\$ 1,613$ billion was

6. For a recent discussion of the underweight position of U.S. equities in foreign portfolios, see Carol C. Bertaut and Linda S. Kole, "What Makes Investors Over- or Underweight? Explaining International Appetites for Foreign Equities" (Board of Governors of the Federal Reserve System, January 2004).

7. See Magnus Dalquist, Lee Pinkowitz, René Stultz, and Rohan Williamson, "Corporate Governance and the Home Bias," Journal of Financial and Quantitative Analysis, vol. 38 (March 2003), pp. 87-110.

8. Estimates from Morgan Stanley Capital International (MSCI) for June 2000 indicate a float of 92 percent for the U.S. and U.K. equity markets but one of only 80 percent on average for the euro-area market and one of 65 percent for the Japanese market. See "MSCI Consultation Paper on Free Float-Adjusting Constituent Weights and Increasing the Target Market Representation in Its Indices" (MSCI, September 17, 2000), available at www.msci.com/provisional/ archives/ConsultationPaper.pdf.

9. Because of the prevalence of securities in the U.S. economy, however, the ICAPM distribution may overstate the relative importance that foreign investors wish to give U.S. securities. For example, although the ICAPM gives the United States roughly a 50 percent weight based on financial market size and a 58 percent weight based on float-adjusted market size, a distribution based on relative GDPs would give the United States a weight of roughly one-third. 
equity, \$502 billion was long-term debt, and \$147 billion was short-term debt. The United Kingdom, which was by far the first choice of U.S. international investors at the end of 2001, attracted more than 22 percent of all U.S. investment in foreign securities; it was followed in popularity by Japan and Canada (chart 7). In the preceding survey, at year-end 1997, the United Kingdom and Japan had also attracted the highest and second-highest levels, respectively, of U.S. investment; the only other U.S. asset survey showed that as of March 1994 Japan had attracted the greatest U.S. holdings, followed by the United Kingdom. ${ }^{10}$

It is perhaps surprising that Bermuda, a country with a population of about 65,000 and a GDP of about $\$ 2$ billion, attracted $\$ 124$ billion in U.S. investment. The size of the U.S. investment primarily reflects the fact that several large institutions have changed their country of incorporation from the United States to Bermuda, transforming U.S. holdings of U.S. securities into U.S. holdings of Bermudan securities. Bermuda's situation highlights an important fact about the measurement of cross-border securities holdings: Securities are attributed to countries on the basis of the country in which a company is incorporated or otherwise legally established, not the country of the company's center of economic activity. ${ }^{11}$

Other unusual patterns are also worth highlighting. Data on U.S. holdings of Swiss securities show $\$ 76$ billion invested in Swiss equities and only $\$ 1$ billion invested in Swiss debt. This finding reflects the

10. For findings from the 2001 survey, see www.treas.gov/tic/ fpis.html.

11. This practice is followed to be consistent with international guidelines on the measurement of balance of payments.

7. U.S. holdings of foreign securities, by selected country of issuer, December 31, 2001

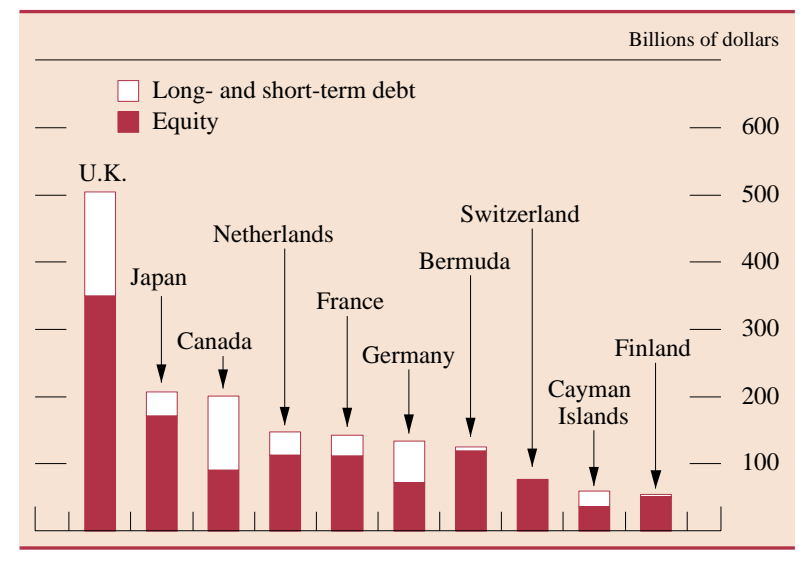

NotE. U.S. holdings of all other foreign securities total $\$ 600$ billion. fact that Swiss firms and Swiss governmental organizations have issued relatively little debt, whereas the Swiss equity market was the world's ninth largest at the end of 2001.12 A high percentage of short-term debt holdings (those with an original maturity of one year or less) is attributed to the United Kingdom, a result, perhaps, of the tendency of internationally active financial firms to issue short-term debt through their U.K. offices. Further, the level of U.S. investment in Canadian long-term debt securities is unusually high: The $\$ 105$ billion figure represents more than 20 percent of all U.S. holdings of foreign longterm debt securities.

Whereas the countries of residence of foreign holders of U.S. securities are difficult to determine, the countries of origin of foreign securities held by U.S. residents are relatively easy to determine and should be completely accurate. Precise country attribution of foreign securities is possible because the surveys collect data on each security held by U.S. owners, and establishing the country of the issuer of foreign securities is typically a straightforward process.

\section{U.S. Holdings, by Currency}

Both the 1997 and 2001 asset surveys show that U.S. investors had a strong preference for foreign debt securities denominated in U.S. dollars; the share of U.S.-dollar-denominated long-term securities increased from 58 percent in 1997 to 67 percent in 2001 (table 1). The preference for U.S.-dollardenominated foreign debt was even stronger in shortterm securities: In the 2001 survey, 84 percent of such holdings were denominated in U.S. dollars.

Almost all of the foreign debt holdings not held in U.S. dollars were denominated in euros, yen, U.K. pounds, and Canadian dollars.

\section{U.S. Holdings as a Share of the Total Outstanding}

Data from the 1994, 1997, and 2001 U.S. asset surveys indicate that as U.S. holdings of foreign equities have increased, so have they increased as a share of total foreign equity market capitalization: from less than 6 percent in 1994 to about 10 percent in 1997 and to 11.5 percent in 2001 (table 2). U.S. investors

12. The Swiss government has relatively little debt because it does not tend to run budget deficits. Swiss corporations also have little debt because of a stamp tax on corporate debt issued in Switzerland. The tax has prompted Swiss firms to issue debt securities through their foreign affiliates. 
1. Distribution of U.S. holdings of foreign debt securities, by currency of denomination, December 31, 1997 and 2001 Billions of dollars except as noted

\begin{tabular}{|c|c|c|c|c|c|c|}
\hline \multirow{3}{*}{ Currency } & \multirow{2}{*}{\multicolumn{2}{|c|}{$\begin{array}{c}1997 \\
\text { Long-term }\end{array}$}} & \multicolumn{4}{|c|}{2001} \\
\hline & & & \multicolumn{2}{|c|}{ Long-term } & \multicolumn{2}{|c|}{ Short-term } \\
\hline & Amount & Percent & Amount & Percent & Amount & Percent \\
\hline U.S. dollar & 315 & 58 & 334 & 67 & 123 & 84 \\
\hline Euro $^{1} \ldots \ldots$ & 75 & 14 & 90 & 18 & 7 & 5 \\
\hline Yen $\ldots \ldots \ldots \ldots$ & 30 & 5 & 25 & 5 & 12 & 8 \\
\hline Canadian dollar & 42 & 8 & 22 & 4 & 1 & 1 \\
\hline U.K. pound .... & 26 & 5 & 16 & 3 & 3 & 2 \\
\hline Other ...... & 39 & 7 & 15 & 3 & 1 & 0 \\
\hline Unknown & 20 & 4 & $*$ & 0 & $*$ & 0 \\
\hline Total & 547 & 100 & 502 & 100 & 147 & 100 \\
\hline
\end{tabular}

Note. Here and in the following tables, components may not sum to totals because of rounding.

1. Amount for 1997 is denominated in the former national currencies of countries now in the euro area (for those countries, see general note to chart 4).

notably increased their shares of the equity markets in the United Kingdom, Japan, and other Asian countries, but they held a relatively constant fraction of the Canadian equity market. Although they held progressively larger dollar amounts of equities of countries in the euro area, the share of the euro-area equity market that these holdings represented declined somewhat in 2001 after increasing from 1994 to 1997. To some extent, differences in the fractions of foreign equity markets held by U.S. investors reflect differences in the float of these countries. Data using float-adjusted estimates of market capitalization show that in 2001 U.S. investors held about 17 percent of the U.K. equity market, about 16 percent of the euro-area market, and a bit under 12 percent of the Japanese market. ${ }^{13}$

13. Alan Ahearne, William L. Griever, and Francis E. Warnock, "Information Costs and Home Bias: An Analysis of U.S. Holdings of Foreign Equities," Journal of International Economics (forthcoming), find little evidence that direct barriers to investment explain U.S. investors' portfolios; rather, information costs associated with foreign companies, regulatory and accounting environments, and financial information may play a role. Using data from the U.S. asset surveys of 1994 and 1997, they find that U.S. investors are significantly more
* Less than $\$ 500$ million.

SOURCE. U.S. Department of the Treasury, Report on U.S. Holdings of Foreign Securities, Foreign Portfolio Investment Benchmark Surveys (May 2003), p. 11 (www.treas.gov/tic/shc2001r.pdf).

In contrast to their investment pattern in foreign equities, U.S. investors have continued to hold a relatively small fraction of foreign long-term debt securities (table 3 ). U.S. investors continue to hold a notably larger share of the Canadian long-term debt market than they do of other foreign markets. As with holdings of foreign equities, the U.S. share of the U.K. long-term debt market in 2001 was larger than that of the euro-area market for long-term debt and larger still than that of the Japanese long-term debt market.

The rise and fall of holdings shown in table 3 for "other Asia" and "other" countries (the latter of which include Latin America) from 1994 to 2001 may reflect a change in the perceived risk-adjusted rate of return on emerging-market debt over the period. Some research indicates that as U.S. investors moved out of emerging-market debt over the 19972001 period, they did so to a greater degree in countries (such as some in Southeast Asia and Latin

likely to hold equities of foreign firms that have reduced such costs by publicly listing securities in the United States.

2. U.S. holdings of foreign equities: Market value and percentage of the foreign equity market, by selected country of origin and for all foreign countries, 1994, 1997, and 2001

Billions of dollars except as noted

\begin{tabular}{|c|c|c|c|c|c|c|}
\hline \multirow{2}{*}{ Country or region } & \multicolumn{2}{|c|}{ March 1994} & \multicolumn{2}{|c|}{ December 1997} & \multicolumn{2}{|c|}{ December 2001} \\
\hline & Amount & Percentage & Amount & Percentage & Amount & Percentage \\
\hline United Kingdom . & 100 & 8.2 & 218 & 10.9 & 350 & 15.8 \\
\hline Euro area .......... & 130 & 7.4 & 376 & 12.5 & 462 & 10.7 \\
\hline Canada........ & 40 & 12.6 & 71 & 12.5 & 90 & 12.8 \\
\hline Japan ...... & 99 & 2.6 & 136 & 6.2 & 171 & 7.6 \\
\hline Other Asia & 51 & 3.4 & 75 & 5.3 & 131 & 6.3 \\
\hline Other ...... & 147 & 9.4 & 332 & 12.7 & 410 & 16.9 \\
\hline All & 567 & 5.6 & 1,208 & 10.2 & 1,613 & 11.5 \\
\hline
\end{tabular}

Note. For the size of the foreign equity market, see source note to chart 4 . For countries in the euro area and in other Asia, see general note to chart 4. 
3. U.S. holdings of foreign long-term debt: Market value and percentage of the foreign long-term debt market, by selected country of origin and for all foreign countries, 1994, 1997, and 2001

Billions of dollars except as noted

\begin{tabular}{|c|c|c|c|c|c|c|}
\hline \multirow{2}{*}{ Country or region } & \multicolumn{2}{|c|}{ March 1994} & \multicolumn{2}{|c|}{ December 1997} & \multicolumn{2}{|c|}{ December 2001} \\
\hline & Amount & Percentage & Amount & Percentage & Amount & Percentage \\
\hline United Kingdom & 20 & 3.7 & 54 & 6.3 & 72 & 5.5 \\
\hline Euro area $\ldots \ldots \ldots$ & 87 & 1.9 & 116 & 2.0 & 137 & 2.0 \\
\hline Canada $\ldots \ldots \ldots$ & 69 & 14.7 & 107 & 18.2 & 105 & 16.4 \\
\hline Japan ...... & 32 & .8 & 30 & .8 & 25 & .5 \\
\hline Other Asia . & 9 & 2.2 & 41 & 5.8 & 21 & 1.5 \\
\hline Other $\ldots \ldots \ldots \ldots$ & 93 & 5.0 & 200 & 8.9 & 143 & 5.5 \\
\hline All & 304 & 2.6 & 547 & 3.9 & 502 & 2.9 \\
\hline
\end{tabular}

Note. For the size of the foreign long-term debt market, see text note 5 . For countries in the euro area and in other Asia, see general note to chart 4.

America) with low and declining credit rates and volatile returns. ${ }^{14}$

With the method used above for foreign portfolios, we can measure the relative weights of foreign equities and foreign long-term debt in U.S. portfolios. Although the share of the aggregate U.S. portfolio held in foreign equities rose between 1994 and 2001, it remained relatively underweight in foreign equities (chart 8, bars labeled "All"). The increase in share of all foreign equities was associated with increases in holdings of Japanese, U.K., euro-area, and other Asian equities. In contrast, the U.S. portfolio weight of Canadian equities decreased a bit, from 0.30 to 0.26 , over this period.

14. John D. Burger and Francis E. Warnock, "Diversification, Original Sin, and International Bond Portfolios," International Finance Discussion Papers 755 (Board of Governors of the Federal Reserve System, January 2003).

8. Relative weight of foreign equities in U.S. equity portfolio, by selected country of origin and for all foreign countries, 1994, 1997, and 2001

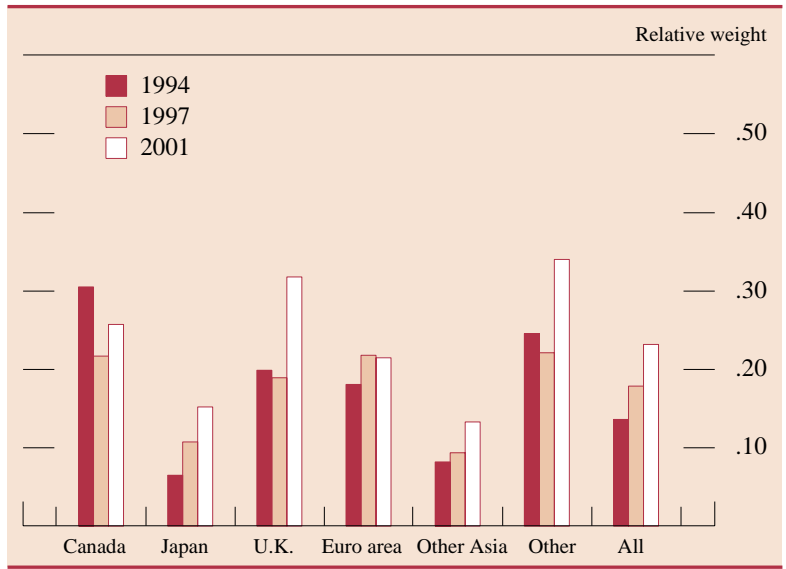

Note. For calculation of relative weights, see text. For countries in the euro area and in other Asia, see note to chart 4.
U.S. investors remain notably more underweight in holdings of foreign long-term debt than in holdings of foreign equities. The relative weight of all foreign long-term debt holdings in the United States barely increased, from 0.06 to 0.08 , between 1994 and 1997 and then slipped back to 0.07 by 2001 (chart 9, bars labeled "All"). Relative to their holdings of all foreign long-term debt securities, U.S. investors are considerably less underweight in holdings of Canadian securities and slightly less underweight in holdings of U.K. securities. The limited participation of U.S. investors in foreign long-term debt markets may partly reflect their apparent preference for securities denominated in U.S. dollars. Indeed, this preference may account for the larger U.S. portfolio weight of Canadian long-term debt: In 2001, roughly two-thirds of Canadian international long-term debt was denominated in U.S. dollars, whereas only 8 percent of all international long-term debt was

9. Relative weight of foreign long-term debt in U.S. longterm debt portfolio, by selected country of origin and for all foreign countries, 1994, 1997, and 2001

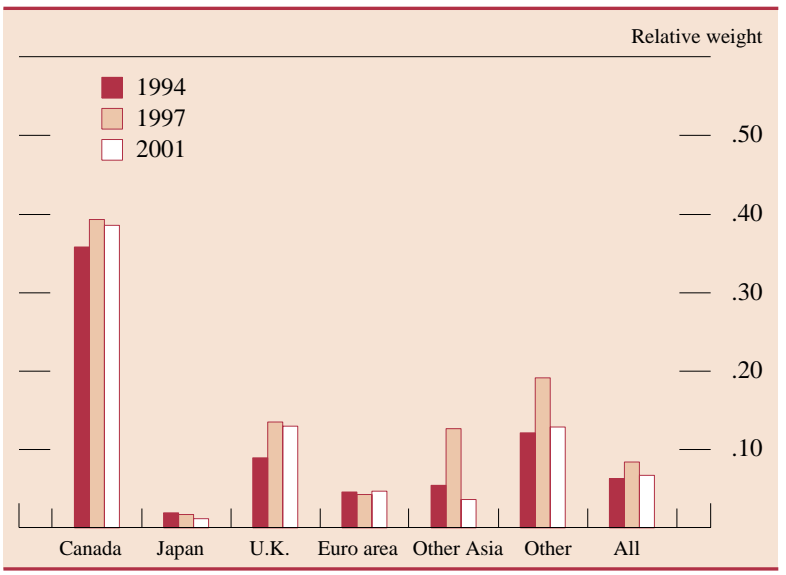

Note. For calculation of relative weights, see text. For countries in the euro area and in other Asia, see note to chart 4. 
dollar-denominated. ${ }^{15}$ Another possible reason for the relatively low measure of U.S. holdings of foreign long-term debt is that such holdings may not fully account for U.S. holdings of foreign bearer bonds, which are difficult to measure.

\section{CHARACTERISTICS AND LEVELS OF U.S. AND FOREIGN HOLDINGS}

The composition of U.S. holdings of foreign securities is quite different from that of foreign holdings of U.S. securities. U.S. investors have primarily held foreign equities, and their preference for equities has increased over the period during which the United States has conducted asset surveys. If we consider only U.S. holdings of foreign long-term securities (the 2001 survey was the first to measure holdings of short-term securities), we find that as of the end of March 1994, 65 percent of U.S. foreign holdings were equity securities; the share increased to 69 percent as of year-end 1997 and to 76 percent as of year-end 2001. In sharp contrast, foreign investors primarily hold U.S. debt securities. Again considering only long-term securities, we see that during the period covered by U.S. surveys of foreign holdings (1974-2002), the proportion of equities in foreign holdings was 36 percent in December 1974, varied in the ensuing years between 31 percent and 48 percent, and was 37 percent in June 2002. Much of this fluctuation appears to be due to booms and busts in the U.S. equity markets rather than to a change in the pattern of foreign investment flows.

Another difference between U.S. and foreign investors is the relative participation of private and official investors. Foreign official investors accounted for a significant though declining share of foreign holdings of U.S. securities over the period, representing 41 percent of all foreign holdings in 1974 and 20 percent in June 2002. In contrast, private investors account for almost all U.S. holdings of foreign longterm securities.

The holdings of foreign official institutions, composed primarily of debt securities, help to explain the difference in the share of equities in U.S. and foreign

15. Data are from BIS international debt statistics, available at www.bis.org/statistics/secstats.htm. The BIS definition of international long-term debt securities differs from the survey definition of foreign long-term debt securities in that, in addition to all securities issued in foreign countries, the BIS definition includes securities issued domestically by resident firms that are denominated in foreign currencies or that are specifically targeted at nonresident investors. See Bank for International Settlements, "Guide to the International Financial Statistics," BIS Papers, no. 14, pp. 13-14, available at www.bis.org/publ/bispap14.pdf.
4. Market value of U.S. holdings of foreign long-term securities and of foreign holdings of U.S. long-term securities, selected dates, 1994-2003

Billions of dollars except as noted

\begin{tabular}{|c|c|c|c|c|}
\hline $\begin{array}{c}\text { Month } \\
\text { and } \\
\text { year }\end{array}$ & $\begin{array}{c}\text { U.S. } \\
\text { holdings }\end{array}$ & $\begin{array}{l}\text { Foreign } \\
\text { holdings }\end{array}$ & $\begin{array}{l}\text { Ratio of } \\
\text { U.S. holdings } \\
\text { to foreign } \\
\text { holdings }\end{array}$ & $\begin{array}{l}\text { Net foreign } \\
\text { holdings }\end{array}$ \\
\hline Dec. $1994^{1}$ & $949^{2}$ & 1,244 & .76 & 295 \\
\hline Dec. 1997 & 1,755 & $2,632^{2}$ & .67 & 877 \\
\hline Mar. 2000 & $2,490^{2}$ & 3,558 & .70 & 1,068 \\
\hline Dec. 2001 & 2,115 & $3,970^{2}$ & .53 & 1,855 \\
\hline June 2002 & $2,050^{2}$ & 3,926 & .52 & 1,876 \\
\hline Dec. 2002 & $1,847^{2}$ & $4,149^{2}$ & .45 & 2,302 \\
\hline Nov. 2003 & $1,804^{2}$ & $4,554^{2}$ & .40 & 2,750 \\
\hline
\end{tabular}

1. December 1994 was chosen as the start date because the first survey of U.S. holdings of foreign securities was conducted in March 1994 (thus, estimates for earlier dates are unreliable), and a survey of foreign holdings of U.S. securities was conducted as of year-end 1994.

2. Estimate. Year-end estimates are from the Department of Commerce, Bureau of Economic Analysis; all others are from the Board of Governors of the Federal Reserve System. For each date except December 2002 and November 2003 , one position was measured by an asset or liabilities survey and the other by adding transactions adjusted for changes in prices and exchange rates to the amounts measured by the last such survey. For December 2002 and November 2003, both positions are estimated.

Source. U.S. Treasury, Report on U.S. Holdings of Foreign Securities, various years.

cross-border portfolios. But even if these holdings are excluded, the share of foreign equities in U.S. investors' cross-border portfolios is still well above that of U.S. equities in the portfolios of foreign investors.

The market value of foreign holdings of U.S. longterm securities has long exceeded that of U.S. holdings of foreign long-term securities (table 4). From December 1994 to November 2003 the difference widened, as the ratio of U.S. holdings to foreign holdings declined from 0.76 to 0.40 .

\section{EFFORTS TO IMPROVE THE MEASUREMENT OF CROSS-BORDER INVESTMENT IN SECURITIES}

As cross-border security flows have become increasingly important, efforts to improve the measurement of these data have intensified. These efforts took on greater urgency in the aftermath of the financial crises of 1997-98, when the lack of relevant and comprehensive data on the external debt and reserve assets of many emerging-market countries was widely perceived as contributing not only to the severity of the crises and but also to the absence of forewarning.

These efforts to improve the quality of data have mainly occurred under the auspices of the International Monetary Fund (IMF). The IMF has also sought to have these data produced within a consistent framework and in a more transparent manner. These efforts have prompted significant changes in 
the U.S. system for collecting data on cross-border securities activity. For example, surveys of portfolio assets and liabilities are now conducted annually, and the U.S. measurement system is increasingly becoming part of an integrated worldwide system.

\section{Recent Efforts to Improve Asset Data}

Internationally coordinated efforts to improve data on assets (holdings of foreign securities by domestic residents) preceded serious efforts to improve liabilities data. IMF-led studies of the accuracy of crossborder financial information concluded that, for securities, measures of worldwide cross-border assets were significantly less than corresponding measures of liabilities despite the fact that these measures should be equal. ${ }^{16}$ To help address this apparent undercount of assets, the IMF organized a Coordinated Portfolio Investment Survey (CPIS) to be conducted as of year-end 1997. Twenty-nine countries participated in the survey, which increased the worldwide level of measured holdings of portfolio assets from $\$ 6.9$ trillion to $\$ 7.7$ trillion. The perceived success of this effort and the desire for further improvements led to a second coordinated survey as of year-end 2001 and to an agreement to conduct such surveys annually. ${ }^{17}$ For the 2001 survey, the number of participating countries more than doubled, to sixty-seven, and the level of measured assets also rose sharply, to $\$ 12.6$ trillion.

Despite the improvements in measurement arising from the surveys, however, worldwide measured assets have remained well below worldwide mea-

16. See International Monetary Fund, Final Report of the Working Party on Statistical Discrepancies in the World Current Account Balance (1987) (Estava Report) and Final Report of the Working Party on the Measurement of International Capital Flows (1992) (Godeaux Report).

17. The IMF consolidates the data from these surveys and posts them, along with analytic tables, on its web site (see www.imf.org/ external/np/sta/pi/cpis.htm). Also available at the site are explanations of the survey techniques of participating countries and directions for obtaining additional information.

5. Estimates of worldwide holdings of securities, December 31, 1997 and 2001

Trillions of dollars except as noted

\begin{tabular}{c|r|c|c|c}
\hline \multirow{2}{*}{ Year } & \multirow{2}{*}{ Assets } & Liabilities & \multicolumn{2}{|c}{ Liabilities minus assets } \\
\cline { 4 - 5 } & & & Amount & $\begin{array}{c}\text { Percent of } \\
\text { liabilities }\end{array}$ \\
\hline $1997 \ldots \ldots .$. & 7.7 & 9.3 & 1.6 & 18 \\
$2001 \ldots \ldots$. & 12.6 & 15.0 & 2.4 & 16 \\
\hline
\end{tabular}

SourCE. International Monetary Fund, Statistics Department. sured liabilities. Data compiled by the IMF show that the percentage difference between measured assets and measured liabilities is dropping but is still quite large, and the absolute difference is growing (table 5). Further, these figures probably understate the discrepancy, as the IMF believes that worldwide liabilities may be significantly underestimated because of a variety of measurement problems. ${ }^{18}$

At least four factors are believed to contribute to the undercount of assets. First, some major investing countries either do not conduct asset surveys or conduct surveys whose quality could be improved. Second, asset surveys measure holdings of foreign securities by domestic residents and tend to collect data from large, institutional units. Thus, foreign holdings not owned by or entrusted to large domestic institutions will typically be missed. In total, such holdings may be sizable. (Below we discuss a partial solution to this problem.) The third problem is bearer bonds. Because of a dearth of information about the owners of these securities, the amounts held by residents of each country must be estimated and may well be undercounted. Finally, investors may wish to obscure their asset holdings in a variety of ways - which may include holding bearer bonds - to avoid paying taxes.

Although the first of these four points is also true of the measurement of liabilities, the others are unique to the measurement of assets. Whereas liabilities consist of foreign holdings of domestic securities-which, because they are registered with public authorities, are typically easy to identifyassets are often held by individual investors whose activities are unknown to data compilers. Bearer bonds issued by domestic residents are likewise easily identified and counted as liabilities (though the foreign-held amounts must be estimated), but holdings of foreign bearer bonds by domestic residents are extremely difficult to identify. And although investors may hide their asset holdings to avoid paying taxes, issuers of domestic securities can usually

18. In its analysis of the difference between estimated assets and estimated liabilities in the worldwide portfolio as of year-end 2001, the IMF stated:

The estimate for portfolio investment liabilities outstanding is more likely to be underestimated than overestimated because (a) some major financial centers do not measure their portfolio investment liabilities; (b) there is a tendency for portfolio investment liabilities (in country International Investment Position statements) to be reported at nominal values rather than at current market prices; and (c) part of the estimate is derived from the summing of flows, which, over the long term, for equities, in particular, tend to underestimate the current market value. The net result is that the under-coverage of assets in the CPIS may be significantly larger than $\$ 2.4$ trillion.

See www.imf.org/external/np/sta/pi/globaldi.htm. 
treat interest and dividend payments as tax deductions. For these reasons, the overall level of measured liabilities is probably more accurate than that of measured assets, but the geographic attribution of measured assets is superior to that of measured liabilities.

\section{Recent Efforts to Improve Liabilities Data}

For many countries, foreign holdings of securities are a primary component of their external debt positions. IMF-led efforts to improve these data resulted, first, in an expanded system for reporting reserve asset positions and, later, in a comprehensive plan for measuring external debt. Both reporting systems have been integrated into an existing IMF system known as the Special Data Dissemination Standard, or SDDS. ${ }^{19}$ To meet the requirements of the external debt reporting system, the United States has begun to conduct annual surveys of foreign holdings of U.S. securities and has made other system modifications. The external debt reporting system began operating as of September 30, 2003.

An important aspect of the SDDS is that the IMF, with country approval, conducts periodic in-country reviews of the methods and procedures that each country uses to compile data. ${ }^{20}$ These reviews cover areas such as methodological soundness, data accuracy and reliability, the independence and integrity of compilers, the strength of the legal framework authorizing data collections, and, in some cases, the views of private-sector data users on the overall reliability and usefulness of each country's data. The IMF produces reports of findings and, again with country approval, publishes the reports on its web site. The IMF's site does not indicate instances in which a country chose not to have the report of findings published.

\section{PROBLEM AREAS AND IMPROVEMENT INITIATIVES}

Most avenues currently under consideration to improve cross-border securities data involve internationally coordinated efforts, as countries face both

19. For more information, see dsbb.imf.org/Applications/web/ sddshome.

20. The IMF review system is called Reports on the Observance of Standards and Codes, or ROSCs (www.imf.org/external/np/rosc/ rosc.asp). Reviews are conducted for countries subscribing to the SDDS and to the less rigorous General Data Dissemination System (GDDS). practical and theoretical limits to what they can do with only domestic sources of information.

As noted above, a gap in the current international measurement system involves holdings of foreign securities entrusted to nonresident institutions for safekeeping. For example, a resident of country A may buy a security issued by a resident of country B and entrust the safekeeping of this security to a bank in country B. If a large domestic institution owns these holdings, then they will probably be captured by country A's portfolio asset surveys, as these surveys typically collect information from large domestic end-investors, or large domestic custodians, or both. But if smaller institutional units or private individuals own these holdings, then they will probably not be reported on country A's asset surveys. However, they will in all likelihood be captured on the liabilities survey of country B, creating an asymmetry between measured assets and measured liabilities.

Further, if the resident of country A instead entrusts the security to a custodian bank in country $\mathrm{C}$, then these holdings will most likely be recorded by country B as liabilities vis-à-vis country C. These holdings will not be included in the asset survey of country $\mathrm{C}$, as asset surveys at present measure only holdings of foreign securities by domestic residents and exclude holdings of foreign securities by foreign residents. To address this problem, counterparty countries must collect the relevant data and exchange this information with authorities in investor countries. In many cases such reporting would require counterparty countries to enhance their reporting systems. Steps to rectify this gap are still in the early stages, but concerned parties are increasingly recognizing the need to address the issue.

Another problem mentioned above is the difficulty of obtaining accurate geographic attribution of liabilities data. Because countries can accurately determine the geography of their asset holdings but not that of their liabilities, the obvious solution is to use asset data from counterparty countries to determine the geography of each country's foreign liabilities. However, such comparisons are best done when countries conduct simultaneous asset and liabilities surveys and when countries have sufficient faith in counterparty asset surveys to feel comfortable using these data in place of their own measurements of liabilities. Although many countries are improving the quality of their asset surveys, the U.S. liabilities surveys are not synchronized with them. The coordinated asset surveys are conducted as of December 31, whereas the U.S. liabilities surveys are conducted as of June 30 , a disjunction that somewhat reduces the 
usefulness of counterparty data for the United States. $^{21}$

\section{SUMMARY}

Now that asset and liabilities surveys are conducted annually, U.S. data on cross-border securities holdings should be on more solid footing. Survey data are more timely and are becoming increasingly reliable as survey reporters gain experience in providing these data. However, problems with the geographic attribution of liabilities data will remain unresolved at least for the short term.

Many other countries, urged on by organizations such as the IMF, have notably improved the quality and transparency of their measurement systems. Data collectors will likely make further significant improvements in the next few years, but problems such as the worldwide undercount of assets are far from being resolved.

\section{APPENDIX: COMPARING U.S. AND FOREIGN MEASUREMENT OF HOLDINGS OF U.S. SECURITIES}

To further assess the extent to which foreign countries own U.S. securities, one may compare the results of U.S. liabilities surveys to the foreign holdings of U.S. securities reported in the 1997 and 2001 Coordinated Investment Portfolio Surveys (CPIS), organized by the IMF. ${ }^{22}$ The country asset surveys show holdings of U.S. securities as well as each country's holdings of all foreign securities, so the data are particularly useful for comparing a given country's exposure to U.S. securities with its foreign exposure more generally. The asset surveys may also provide more accurate information on holdings of U.S. securities by nonresident custodians in a given country. For example, the U.S. liabilities surveys may overestimate holdings in international financial centers, where such custodians frequently are located, and consequently these surveys may underestimate holdings for the countries of the actual owners of these securities. To the extent that the CPIS asset surveys are able to properly allocate holdings by nonresident custodians, they may be able to give a more accurate picture of the country distribution of foreign holdings of U.S. securities.

21. Many U.S. survey reporters were concerned that conducting both surveys as of year-end would place an undue burden on their resources. In response, the United States staggered the schedule for collecting these data.

22. For availability of reports, see text note 17 .
On the other hand, the set of countries that conducted asset surveys is not as large as the set of countries to which we can attribute ownership in the U.S. liabilities surveys, so the universe of foreign holders will underestimate total holdings of U.S. securities. For example, China, a major holder from our liabilities surveys, has not conducted asset surveys. Another important difference for the 2001 asset surveys is that the publicly released country-level data from these surveys exclude holdings of foreign securities held as foreign exchange reserves. ${ }^{23}$ Such liabilities to foreigners are included in the U.S. liabilities surveys. ${ }^{24}$ Differences in survey techniques may also result in differences in reported holdings between the two types of surveys; for example, not all countries conduct security-level surveys, the technique generally believed to be the most accurate. Finally, the difference in timing between the December 2001 assets surveys and the June 2002 liabilities survey can result in differences in reported holdings to the extent that there were net purchases or sales of U.S. securities and changes in the market value of the securities over the six-month period.

For U.S. equities, the change in market value during this time is likely to be especially important, as broad U.S. equity indexes fell about 14 percent in the first half of 2002. For foreign holdings of U.S. longterm debt, the more significant difference is likely to come from securities transactions, as foreign residents purchased a net total of about $\$ 230$ billion in U.S. long-term debt securities over the period.

To construct the foreign portfolios and shares held in U.S. assets shown in charts 5 and 6 , we use information from the CPIS asset surveys and from the U.S. liabilities surveys. For holdings of all foreign equities and of U.S. equities, we use the reported amounts in the CPIS surveys. For holdings of longterm debt securities, we augment the total reported foreign holdings of long-term securities with IMF estimates of total reserve holdings to construct the

23. For 2001, securities held as reserves are reported separately in the IMF's Survey of Geographical Distribution of Securities Held as Foreign Exchange Reserves (SEFER) and not on the CPIS. In the 1997 survey, some countries reported reserve holdings in their CPIS survey, while others reported reserves separately on the SEFER. For details on coverage of the CPIS and the SEFER, see "Portfolio Investment: CPIS Data: Notes and Definitions," available at www.imf.org/external/np/sta/pi/notes.htm.

24. The CPIS collected reserve asset holdings separately from other holdings. The U.S. liabilities surveys measure official holdings separately from other holdings. Although foreign official investors are primarily specific organizations in each country that would be expected to hold their country's reserve assets, the definition of official holdings is broader than that of reserve assets. Published data from the U.S. liabilities surveys do not show official holdings separately from other holdings by country, although we are able to identify these holdings for our analyses. 
total foreign portfolio in each country. For holdings of long-term U.S. securities, we compare the reported CPIS amounts with the amounts in the U.S. liabilities survey, adjusted for net securities purchases during the six-month difference in reporting periods. For countries whose reported CPIS amounts are greater than the U.S. liabilities numbers, we use the CPIS amounts. Although these figures may be underestimates of true holdings of U.S. long-term securities for these countries, as they exclude reserve holdings in U.S. securities, they suggest that our liabilities survey produces an even greater underestimate of nonreserve holdings for these countries. For countries for which the U.S. liabilities survey estimates of holdings are greater, we use the U.S. liabilities amounts. Overall, we find that our liabilities survey estimates of foreign holdings of U.S. securities are larger than the total reported on the asset surveys. 